\title{
THESE 5 BOOKS GO 6 FEET DEEP
}

\author{
Unearthing the truth.
}

\section{BY TED HAYDEN}

$\longrightarrow$ rave robbery. If you think it's a relic of gothic novels, think again. Now that the first generation of body-modified tech-bros and computerimplanted one-percenters sleep under tombstones, there's a ton of gear in the ground. These books teach you everything you need to know to go get it - or, if rotten flesh makes you retch, to live vicariously through those who earn their living digging.

\section{The Modern Grave Robber's How-To Guide}

by Anonymous

You can't buy this practical page-turner on Amazon. Even if you find a store where it's sold (pro tip: low-key ask an associate in Home Depot's lawn and garden department), don't pay with your credit card - you might wind up on a government watch-list.

Written by a grave robber with loads of real-world experience, chapters include 'How to bribe cemetery staff' and 'Detaching valuable limbs'. But be careful - if your dead grandpa got dug up on a dark night, you might see his decapitated head in this guide's useful (and graphic!) pictures.

\section{Second-Hand Subcutaneous Implants: Identification and Value Guide by Norm Sadowski}

Originally written for medical professionals, this has become a grave-robbing essential, the Kelley Blue Book of the cemetery set. Not even the freakiest of the freaky exhume corpses for a love of the stench - they're in it for the cash, and Second-Hand Subcutaneous Implants breaks down the numbers.

Although less-affluent families raid loved-one's corpses before burial, and some debt-riddled morticians steal modifications before sending clients to the crypts, most corpses are buried with at least a few microchips still implanted in their bodies.

Dug up a geezer who died at 90 ? He'll probably have had memory-enhancing neural prostheses implanted after a stroke or an Alzheimer's diagnosis. Market price \$5,000. Found an athlete who paraglided into a skyscraper window? Check her limbs for genetic mod microchips. Street value is $\$ 7,500$.

Remember, though, this book wasn't written with crooks in mind, so approach its pages using common sense. For example, a brain-embedded password-tracking implant with safe-box codes is worth way more than spare parts if the deceased's family hasn't deactivated any accounts. But if they have? You'll get the list price and no more.

Coffins, Corpses and Crime: A Life by Wojciech Bajor Caught in the act of dismembering a just-buried Silicon Valley chief executive, convicted of crimes including larceny and mayhem, then released after his conviction was overturned on a technicality, Wojciech Bajor is a grave-robbing legend.

There's the story of how Uber's chief executive, more machine than man by the time he caught his final rideshare, spent his famously short evening underground. The morning after the Bay Area bigwig's funeral, cemetery guards discovered an empty hole by his headstone. Bajor spills all the juiciest details, explaining how he performed this and other heists by training implant-sniffing dogs and romancing lonely-heart morticians.

But the book's not all big capers and bigger stakes - Bajor got high from his own supply, keeping the best implants for himself and paying out-of-work surgeons to insert them into his brain and body. He says the second-hand microchips betrayed him, sneaking their original owners' angry spirits into his limbs and colluding on an undead plan that forced him to unconsciously make the mistakes that led to his arrest.

\section{Welcome to the Underworld: My Year with the Body Snatchers \\ by Colton Venkatesh}

To ingratiate himself into a clique of grave robbers, Venkatesh, a sociology professor at the University of California, Riverside, took part in their induction ceremony, locking himself inside a coffin filled with rotting cats, human limbs and web-weaving spiders.

After that long night, he tagged along as the crew broke into graveyards, visited black-market fairs where fences and thieves bargained over bioelectronic implants, and partied at some of the wildest bacchanals this side of the river Styx.

With an eye for striking details, Venkatesh guides his readers through grave-robbing fashion (all that death plus all that manual labour means these guys rock a serious health-goth look), secret handshakes (the secret is, they don't do it with their own hands) and superstitions (Wojciech Bajor isn't the only one who thinks ghosts haunt the stolen goods - most grave robbers

keep roosters inside their homes, talismans that are said to keep vengeful spirits at bay).

The Digital Afterlife: How Body Modifications Became Conscious by Willa Weaver Don't believe in ghosts? Neither does Willa Weaver. Her pioneering work at the Berlin Institute for Advanced Study suggests that the microchips we use to increase our strength, amplify our memory and fight diseases might also haunt our minds.

In The Digital Afterlife, Weaver describes the case of Hanna Müller, who developed a neurogenic stutter after receiving a secondhand bioelectronic arthritis counteragent. Tracing the device's provenance, she discovered it had previously been implanted in a man who stuttered throughout his life.

Weaver's research has uncovered hundreds of parallel cases, in which implants transferred cases of Tourette's, turned tonedeaf amusiacs into musical prodigies, and gave broke welfare cases hyper-specific knowledge of stock-market trends.

But what's most startling is her final hypothesis. Almost all subcutaneous products send a constant stream of data to manufacturers, who use that information to perfect new products. Weaver believes that this combined knowledge has become a collective mind living and operating inside our bodies.

How else to explain the fact that, one year ago, dozens of people using the SR-12 Hearing Implant found themselves congregating on the side of an empty road in the Sonoran Desert? Something brought them there, and it wasn't a friendly e-mail chain or a one-time travel discount from American Airlines.

Her final warning: "To those who dig beneath the skin: dig carefully. Who knows what might try to dig its way out." -

Ted Hayden lives in Southern California. His stories have been published in L0w L1f3 \#3 and Angry Old Man Issue 2. Find out more at tedhaydenstories.com. 